Rev. Biol. Neotrop. 3(2): 169-176. 2006

\title{
etection of Paraneuronal Cells in Guppy (Poecilia vivipara) Gill Filament epithelium Determined by Histochemistry and Transmission Electron Microscopy
}

\author{
Rodinelli Borges de Oliveira \\ Eliane Vieira Rosa \\ Valdirene do Nascimento \\ Joana Cristina Neves Menezes-Faria \\ Ana Flávia Vigário \\ Pabline Marinho Vieira \\ Márcia Pereira Cardoso \\ LeandRo Breseghelo \\ Janaína de Sousa Menezes \\ Laboratório de Comportamento Celular, Instituto de Ciências Biológicas (ICB), Departamen- \\ to de Morfologia /Universidade Federal de Goiás, Campus II, 74001-970 Goiânia, Goiás, \\ Brasil

\section{João Roberto da Mata \\ José Oscar Rodrigues de Morais} \\ Laboratório de Neurobiologia, Instituto de Ciências Biológicas (ICB), Departamento de Mor- \\ fologia /Universidade Federal de Goiás, Campus II, 74001-970 Goiânia, Goiás, Brasil

\section{Simone Maria Teixeira de Sabóia-Morais} \\ Laboratório de Comportamento Celular, Instituto de Ciências Biológicas (ICB), Depto de \\ Morfologia /Universidade Federal de Goiás, Campus II, 74001-970 Goiânia, Goiás, Brasil \\ saboias@terra.com.br Autor para correspondência
}

Resumo: Os teleósteos neotropicais possuem complexa organização branquial associada a variadas funções, das quais as mais importantes são: respiração e osmorregulação. Há vários tipos de células envolvidas nessas funções, mas o alvo principal deste estudo são as células neuroepiteliais (NECs), paraneurônios caracterizados pela capacidade de sintetizar e armazenar indolaminas em vesículas granulares cromafins. $\mathrm{O}$ objetivo desta pesquisa foi verificar a ocorrência de NECs nas brânquias de guaru (Poecilia vivipara) por meio de metodologia histoquímica usando o método de Lars Grimelius (método LG) e microscopia eletrônica de transmissão convencional (MET). Observou-se NECs na região interlamelar, dispostas em grupos ou isoladamente na metade distal do filamento, as quais possuem grande quantidade de grânulos marromescuros reativos à técnica de LG. Usando-se cortes seqüenciais, detectou-se células com grânulos eletrodensos posicionadas nas proximidades de vasos sangüíneos, as quais emitiam prolongamentos em várias direções, evidenciando grande atividade celular. Isto leva a supor que estas células agem na regulação das funções branquiais, provavelmente na osmorregulação, por meio da síntese e secreção de mensageiros químicos. Estes resultados confirmam a presença de NECs em brânquias de guaru e podem auxiliar a estabelecer estes animais como modelo biológico para aprimorar estudos destes tipos celulares.

Palavras-chave: brânquia, células neuroepiteliais, guaru, histoquímica, microscopia eletrônica de transmissão.

AвSTRACT: Neotropical teleosts gill show complex organization performing two functions: respiration and osmoregulation. There are several cell types involved in gill epithelial functions, and the target of this study is neuroepithelial cells (NECs), a kind of paraneuronal cell characterized by the ability of synthesizing and storing indolamines in chromaffin granular vesicles. The goal of this study was to verify the presence of NECs in guppy (Poecilia vivipara) gills determined by histochemistry using Lars Grimelius method (LG method) and transmission electron microscopy (TEM) techniques. It was possible to observe NECs in the interlamellar region, either in clusters or isolated on the distal half of the filament, presenting a great amount of dark-brown granules, reactive to LG method. Using sections obtained in microtome, cells with electrodense granules were detected near blood vessels, emitting processes in several directions, evidencing high cellular activity. This fact leads to the hypothesis that these cells act in the regulation of gill functions, probably in the osmoregulation through the synthesis and secretion of chemical messengers. The results confirm the presence of NECs in guppy gills and can be of interest for researchers to utilize this fish species as a potential biological model to refine the study of these type of cells.

KEY wORDs: gill, neuroepithelial cells, guppy, histochemistry, transmission electron microscopy. 


\section{INTRODUCTION}

$\mathrm{F}$ ish gills are structures as sophisticated as the lungs of tetrapods and consist of a complex arrangement of several epithelial cells vascularized by different circulatory circuits. Gills perform two main functions: respiration and osmoregulation. These are important physiological processes and the modulation of the epithelial function is controlled by hormones and neural factors (Zaccone et al., 1995). The fish gill epithelium is characterized by the presence of four cell types: pavement cells (PVCs), mitochondrion-rich cells (MRCs), mucous cells (MCs) and accessory cells (ACs) (Evans et al., 1999). In the last group, there are the paraneurons, the purpose of this study.

PVCs constitute more than $80 \%$ of the filament and lamella epithelium. MRCs and MCs represent approximately $10 \%$ and $2 \%$ of the total number of gill cells, respectively (Leguen et al., 2001). Many other cell types, representing a small percentage of gill cells, have also been identified: endothelial cells, termed pillar cells (Olson, 1991), neuroepithelial cells (NECs) (Dunel-Erb et al., 1982), and undifferentiated cells.

According to Kanno (1998), para-neurons are endocrine and sensory cells that share structural, functional, and metabolic charac-teristics with neurons and produce substances identical or related to neurotransmitters or neurohormones, which are synthesized and secreted by regulated secretion. They are receptoconductile-secretory cells and this function is shared by specific proteins dis-tributed at proper regions of cell membrane.

Fujita \& Kobayashi (1988), on the other hand, affirm that paraneurons are recepto-secretory cells storing substances, such as bioactive peptides, amines or other classic messengers, adenine nucleotides and acidic carrier proteins, including chromogranins. These cells have been located in epithelia and are bipolar due to the fact that they receive information from the external environment and transduce it into chemical messengers, which are released locally by the basal part of the cell.

In some cases, regulatory peptides associated with mammalian skin and lung present a similar chemical structure and anatomical location to the equivalent neu-roendocrine paraneuronal cells of fishes (Zaccone et al., 1994). The
NECs of the fish gill filament are chromaffin cells and they are also a type of paraneuron.

Dunel-Erb et al. (1982) affirmed that formaldehydeinduced fluorescence revealing numerous serotonin-containing cells within the primary epithelium of the fish gill. These cells are isolated or clustered and are supported by the epithelial basal lamina.

Formaldehyde is a chemical reagent that links and recognizes biogenic amines, specially indolamine 5-hidroxytriptamine or serotonin, and locates these cell contents in a reaction that is fluorescent and easily detected through darkfield microscopy (Bancroft \& Stevens, 1982). This method is frequently used to study their frequency and presence in respiratory system of vertebrates and is important to detect isolated and clustered cells near conjunctive tissues, but protected by basal lamina in fish gills and amphibian lungs (Goniakowska-Witalinska et al., 1995; Goniakowska-Witalinska, 1997). The importance of the detection of this cell type with serotonin content in fish is reported in studies that have shown imbalances in serotonin levels triggering depression in humans. In fish, other cells present granules that are very rich in encephalins, probably with regulatory functions (Zaccone et al., 1994). Besides this, the roles of endothelins in the gill also need further investigation based on the multifunctional organization of this organ (Zaccone et al., 1996).

Others methods for detection of NECs have been proposed to study the distribution of substrate metabolites (Carlsson \& Pärt, 2001) and to understand the stimulation and re-gulation of vascular activities in gills (Calabró et al., 2005). These studies are important to understand the functional activities of the respiratory system of various fish species that survive in a variety of habitats with different environmental pressures.

Numerous single NECs can also be observed in the proximal half of the filaments of Perca, Micropterus, Ictalurus, Oncorhynchus, and Acipenser (Bailly et al., 1992). Most of the labeled NECs are isolated cells, but clustered cells are also present in the teleosts. Depending on the species, the NECs emit more or fewer processes in all directions, especially towards the basal lamina of the filament epithelium (Bailly et al., 1992). NECs are present in the gill filament epithelium of teleosts (Dunel-Erb et al., 1982) 
and non-teleosts, such as Scyliorhinus canicula (Laurent, 1984) and Ancipenser baeri (Bailly et al., 1989).

The aim of the present work was to identify the presence of paraneurons in gills of guppy, a euryaline teleost, using histochemical and transmission electron microscopy methods.

\section{Materials AND MEthods Experimental models}

This study was performed on the gills of teleost neotropical species guppy (Poecilia vivipara, Steindachner, 1863), collected in seawater with salinity of $20 \mathrm{ppm}$ and exposed to freshwater. All the fish were fed with commercial fish food, kept in tanks with freshwater at $\mathrm{pH} 6.9$ at room temperature, and their behavior was observed during the experimental exposi-tion.

\section{Procedures to light-field microscopy}

Five fish gills, dissecation of five fish, were analyzed through Light-field Microscopy (LM) using the Lars Grimelius method (LG method) (Grimelius, 1968). The samples were fixed in aqueous Bouin's solution and washed in tap water. Then, the gills were dehydrated in increasing concentrations of ethanol with this routine procedure, and the branchial leaflets were included in paraffin, and subsequenthy 5-mm-thick slices were obtained. The slices were stained using the LG method in an attempt to detect chromaffin cells rich in darkbrown stained granuli. The LG method, used for argyrophilic cells, consists of removing the paraffin from the samples and hydrating them. After this, the samples were immersed in $0.030 \%$ silver nitrate (dissolved in distilled water) at $60^{\circ} \mathrm{C}$ for 2 hours, and $1 \%$ of hydroquinone $+5 \%$ sodium sulfite (1:1) for 1 minute. Then, the samples were washed three times in distilled water and submitted to a solution of $1.5 \%$ sodium tiosulphate for 2 minutes. Finally, the material was dehydrated, the slices were exposed to Entelan and photographed using an Olympus B 071 photomicroscope.

\section{Procedures for transmission electron mi- croscopy}

Five fish gills were fixed in a modified Karnovsky fixing solution and post-fixed in aqueous $2 \%$ osmiun tetroxide, dehydrated in increasing concentrations of ethanol and acetone, and embedded in Spurr's resin. Semithin sections were collected in glass slices and stained with toluidine blue. Sections $-70 \mathrm{~nm}$ - thick, obtained using Sorval-MT2 ultra-microtome, were collected, stained with uranyl acetate and lead citrate, and analyzed with a Zeiss EM9S-2 transmission electron microscope.

\section{Results}

A kind of argyrophilic cell, called NEC, was demonstrated through the LG method. These cells are located at the gill filament epithelium and presented a lot of dark brown granuli, showing a positive reaction to the LG method (Figs. 1 and 2). Argyrophilic cells were also detected in the distal region of branchial filaments in the gills presenting distribution in small isolated clusters.

These data were hystochemically obtained using the LG method and showed possibilities to characterize and identify the NECs through transmission electron mi-croscopy (TEM). Using the location of argyrophilic cells, it was possible to detect cells with electrodense granules, similar to vesicles and to observe that the vesicles showed low electrodensity and revealed various sizes and shapes ranging from spherical to ovoid, maybe according to maturity. These cells were close to the blood vessels (Fig. 3).

The NECs send processes in various directions, specially towards the basal lamina of the filament epithelium (Fig. 4). The main features of argentafin cells were a large nucleus with patches of condensed chro-matin, numerous mitochondria, a well developed Golgi apparatus and a few dense core vesicles of various size scattered in the cytoplasm (Fig. 4).

\section{Discussion}

The data obtained in this study demonstrate that the chromaffin cells were usually located around the blood vessels. However, they were not part of the endothelium of those blood vessels as observed by Furimsky et al. (1996) when studying the rainbow trout (Oncorhynchus mykiss).

The position in which the NECs were located was also observed by Dunel-Erb et 


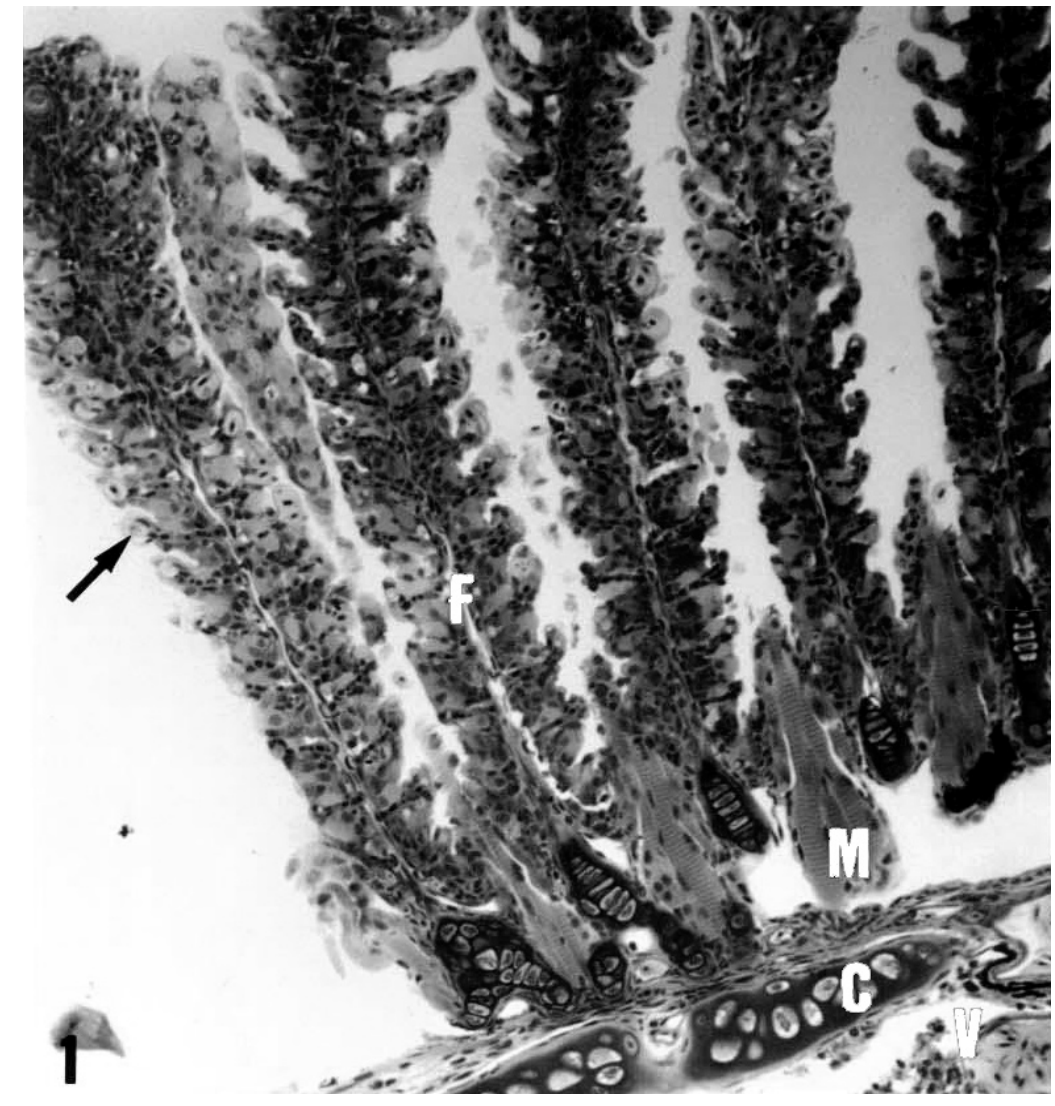

$\overline{172}$

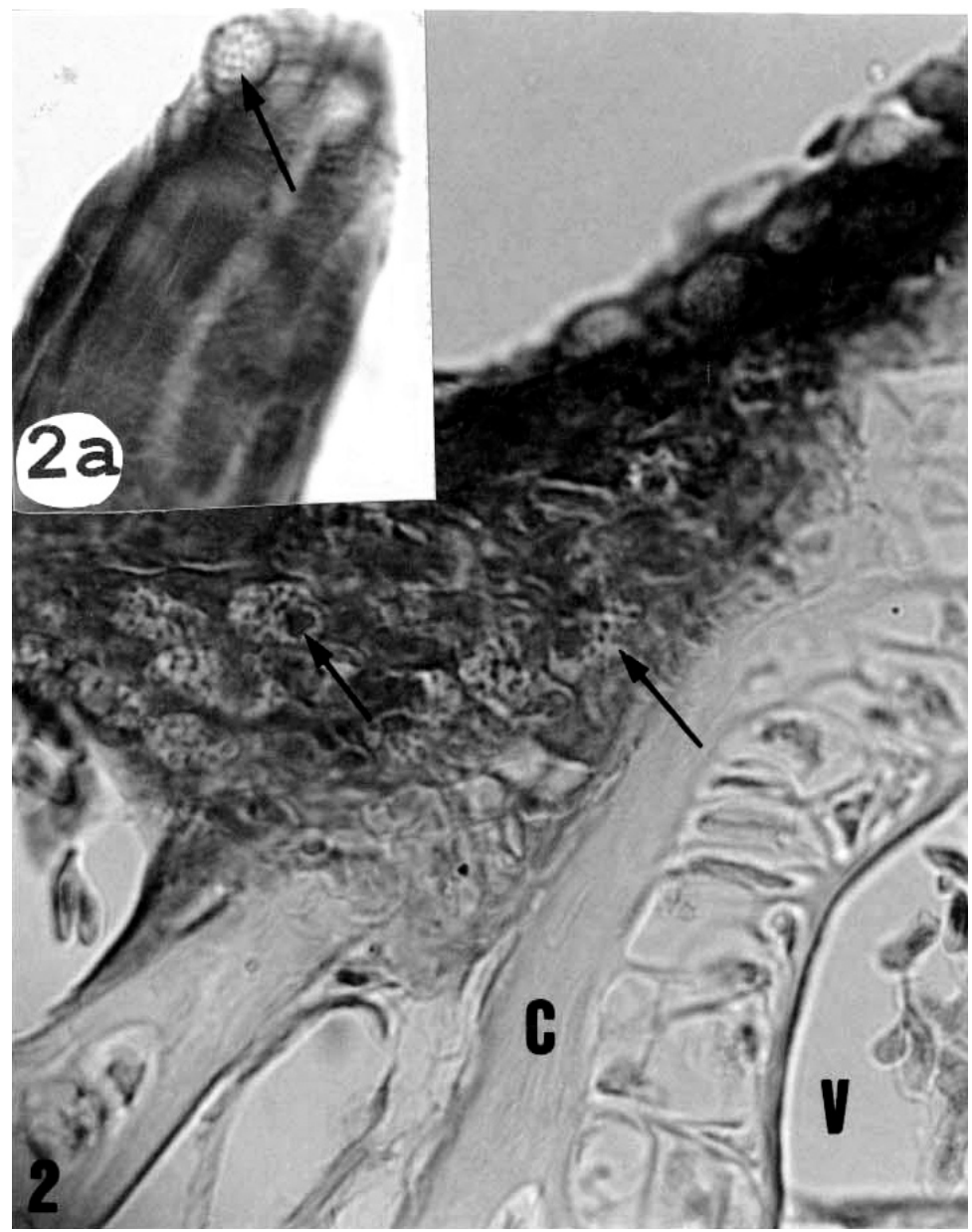

Figure 1 - Photomicrography of semithin section of fish gill showing filaments ( $F)$, secondary lamellae (arrow), muscle (M), cartilage (C) and blood vessel (V) in the arc. Toluidine blue, 500X.
Figure 2 - Photomicrography of interlamellar epithelium. Observed cartilage (C) and vessel (V), in contrast paraneuronal cells (arrows) with positive cytochemistry reaction using the Lars Grimelius method, 900X. In 2a detail of paraneuronal cell (arrow) 900X. 


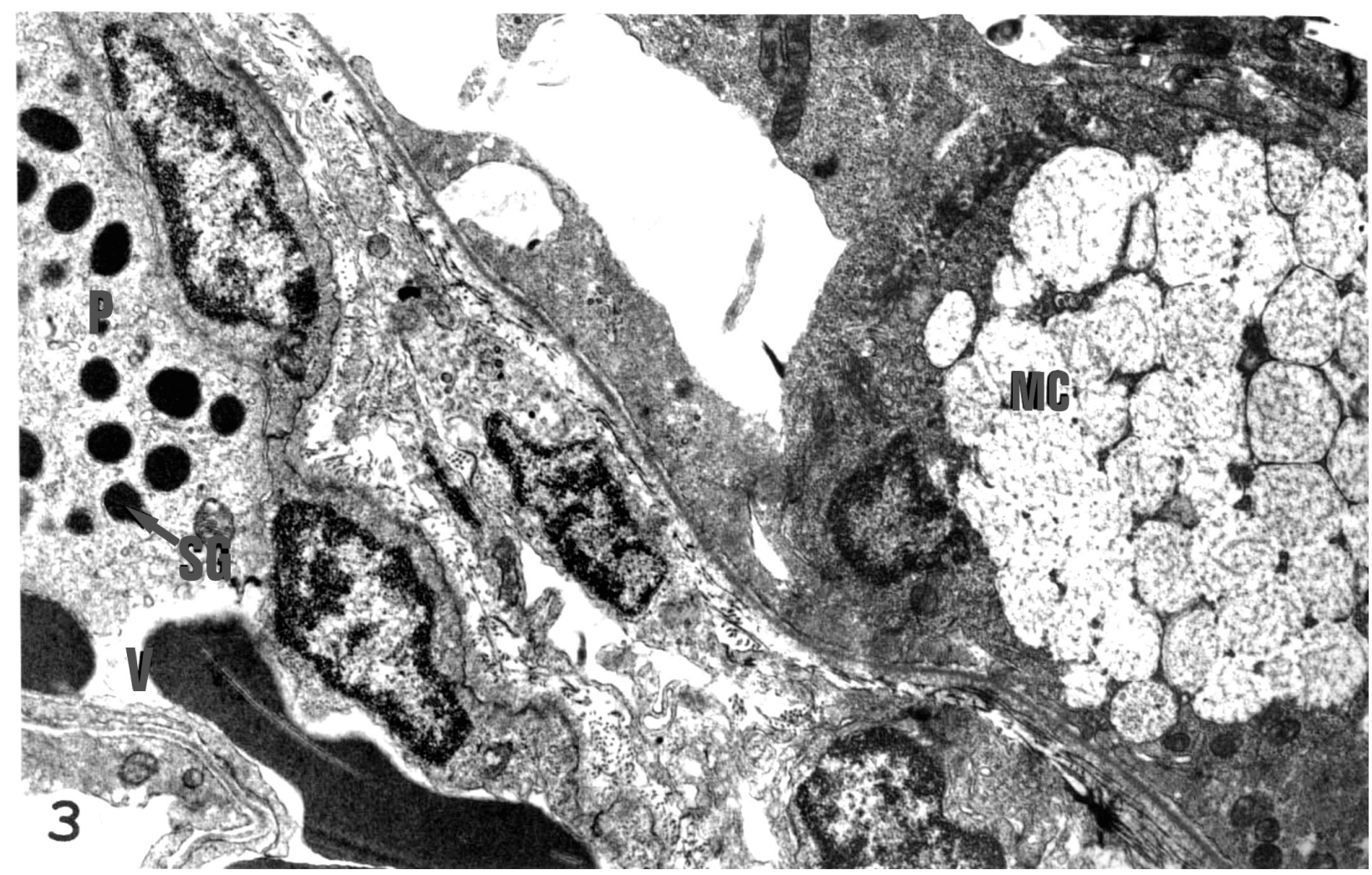

Figure 3 - Eletronmicrography of interlamellar epithelium, showing different types of cells: mucous cell $(\mathrm{MC})$, paraneuronal cell $(\mathrm{P})$ with high electrodense secretory granules (SG and arrow) near the vessel (V) $8,000 X$.

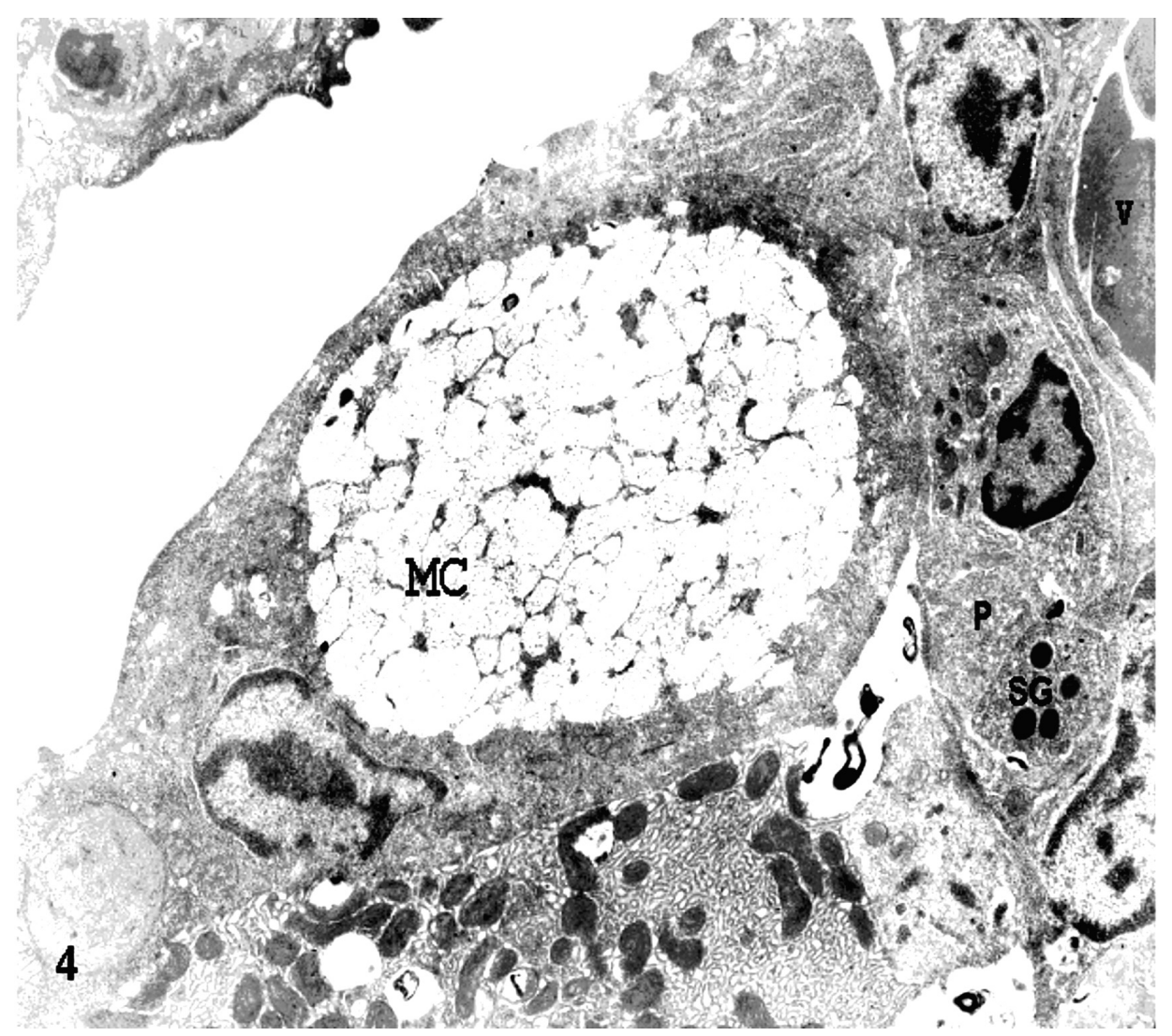

Figure 4 - Eletronmicrography of interlamellar epithelium, showing different types of cells: mucous cell $(\mathrm{MC})$, paraneuronal cell $(\mathrm{P})$ with low electrodense secretory granules (SG) near the vessel $(\mathrm{V}) 8,000 \mathrm{X}$. 
al. (1982) in teleost fish and by Bailly et al. (1992) in one species of chondrostean fish, the sturgeon (Acipenser baeri) and in six species of teleosts: rainbow trout (Oncorhynchus mykiss), perch (Perca fluviatilis), black bass (Micropterus dolomieui), catfish (Ictalurus melas), tilapia (Oreochromis mossambica), and sea perch (Dicentrarchus labrax). However, in the research performed by Bailly et al. (1992), NECs were also identified in the proximal part of the gills filamentous in some species of fish, a fact that was not observed in the present study.

As for the higher vertebrates, both solitary NECs and neuroepithelial bodies (NEBs) share several common cytochemical and ultrastructural characteristics with other NECs: argyrophilic by silver impregnation, fluorescence by formaldehyde-induced cytochemistry, and the presence of dense-cored secretory granules by electron microscopy (Lauweryns \& Cokelaere, 1973; Hage, 1972a,b; Lauweryns et al., 1977). In the rabbit lung, NEBs are revealed by light microscopy using argyrophilic staining (Cutz et al., 1978). Cytoplasmic argyrophilia is also revealed in NECs and NEBs of lung tissues of a large number of vertebrate species (Scheuermann, 1987). In the present work, the LG method was also used in order to perform the analysis through light micros-copy, and NECs were successfully identified in gill filament epithelium of guppy.

The teleosts are so far the only group of fish for which intra-filamental serotonergic neurones and nerve fibres have been shown (Zaccone et al., 1992). Others stores of serotonin in the gills are the NECs and polymorphous granular cells (PGCs) (Dunel-Erb et al., 1982). Similar to the location of the neurones, serotonin-immunoreactive NECs are situated on the efferent side of the filament facing the respiratory water flow (Nilsson \& Sundin, 1998). The PGCs have only been described in rainbow trout (Bailly et al., 1989; Bailly et al., 1992; Dunel-Erb et al., 1982; Zaccone et al., 1992).

The exact function of NECs and the quantity of serotonin contained in them remains unknown. It is well known, though, that serotonin exerts a local vasoconstrictive action in the lung of mammals, in a paracrine way, induced by hypoxia (Fujita \& Kobayashi, 1988). The frequent coexistence of serotonin and peptidic hormones points to a role in the synthesis, storage, and release of regulatory peptides, or in other words, to a trophic function, during development and differentiation and in adaptation of the respiratory system at birth (Zaccone et al., 1995).

Considering this and the fact that NECs are located in the epithelium of the gills, one might conclude that they are bipolar cells in the sense that they receive information from the external environment and transduce it into chemical messengers, which are released locally by the basal part of the cell (Zaccone et al., 1994).

In this study, NECs in gills filamentous of guppy were detected surrounding the blood vessels. These data were also confirmed by Zaccone et al. (1994) and Calabró et al. (2005) in previous studies. These authors showed that these cells act in the branchial function regulations, either in the osmoregulation or in the synthesis of chemical messengers. The NECs of the gill filaments of guppy were observed cytoplasm processes magnify the contact surface, being an evidence of great cellular activity.

The great variety and shapes of chromaffin granular vesicles found in the cytoplasm can be an indicative of distinct substances stored in it, allowing the existence of subpopulations composed of distinct NECs in gills of guppy (P. vivipara), which must be better investigated in further studies by means of more specific methods.

\section{Acknowledgments}

The present study was supported by grants from FUNAPE, CNPq (PIBIC) and UFG (CEMIE - Centro de Microscopia Eletrônica - ICB - UFG).

\section{References}

Bailly, Y., S. Dunel-Erb, M. Geffard \& P. Laurent. 1989. The vascular and epithelial serotonergic innervation of the actino-pterygian gill filament with special reference to the trout, Salmo gairdneri. Cell Tiss. Res. 258:349-363.

Bailly, Y., S. Dunel-Erb \& P. Laurent. 1992. The neuroepithelial cells of the fish gill filaments: indolamine-immunocytoche-mistry and innervation. Anat. Rec. 233: 143-161. 
Bancroft, J. D. \& A. Stevens. 1982. Theory and practice of histological techniques. 2nd ed., Edinburgh, Churchill Livingstone.

Calabró, C., M. P. Albanese, E. R. Lauriano, S. Martella \& A. Licata. 2005. Morphological, histochemical and immunohistochemical study of gills epithelium in the abyssal teleosts fish Coelorhynchus coelorhynchus. Folia Histochem. Cytobiol. 43: 51-56.

Carlsson, C. \& P. Pärt. 2001. 7-Ethoxyresorufin O-deethylase induction in rainbow trout gill epithelium cultured on permeable supports: asymmetrical distribution of substrate metabolites. Aquat. Toxicol. 54: 29-38.

Cutz, E., W. Chan \& K. S. Sonstegard. 1978. Identification of neuro-epithelial bodies in rabbit fetal lungs by scanning electron microscopy: a correlative light, transmission and scanning electron microscopic study. Anat. Rec. 192: 459-466.

Dunel-Erb, S., Y. Bailly \& P. Laurent. 1982. Neuroepithelial cells in fish gill primary lamellae. J. Appl. Physiol. 53:1342-1353.

Evans, D. H., P. M. Piermarini \& W. T. W. Potts. 1999. Ionic transport in the fish gill epithelium. J. Exp. Zool. 288: 641-652.

Fujita, T. \& S. Kobayashi. 1988. The Paraneuron. Tokyo, Springer-Verlag.

Furimsky M., T. W. Moon \& S. F. Perry. 1996. Calcium signalling in isolated single chromaffin cells of the rainbow trout (Oncorhynchus mykiss). J. Comp. Physiol. 166: 396-404.

Goniakowska-Witalinska, L. 1997. Neuroepithelial bodies and solitary neuroendocrine cells in the lungs of amphibia. Microsc. Res. Tech. 37: 13-30.

Goniakowska-Witalinska, L., G. Zaccone, S. Fasulo, A. Mauceri, A. Licata \& J. Youson. 1995. Neuroendocrine cells in the gills of the bowfin Amia calva. An ultrastructural and immunocyto-chemical study. Folia Histochem. Cytobiol. 33: 171-7.

Grimelius, L. 1968. A silver nitrate stain for alpha-2 cells in human pancreatic islets. Acta Soc. Med. Ups. 73: 243-270.

Hage, E. 1972a. Electron microscopic identification of endocrine cells in the bronchial epithelium of human foetuses. Acta Pathol.
Microbiol. Scand. [A] 80: 143-144.

Hage, E. 1972b. Endocrine cells in the bron-chial mucosa of human foetuses. Acta Pathol. Microbiol. Scand. [A] 80: 225-234.

Kanno, T. 1998. Intra-and intercellular $\mathrm{Ca}^{2+}$ signaling in paraneurons and other secretory cells. Jpn J Physiol. 48: 219-227.

Laurent, P. 1984. Gill internal morphology, p. 73-183. In: W. S. Hoar \& D. J. Randall (Eds.), Fish physiology. New York, Academic Press.

Lauweryns, J. M. \& M. Cokelaere. 1973. Hypoxia-sensitive neuro-epithelial bodies. Intrapulmonary secretory neu-roreceptors, modulated by the CNS. Z Zellforsch. Mikrosk. Anat. 145: 521-540.

Lauweryns, J. M., M. Cokelaere, M. De-leersnyder \& M. Liebens. 1977. Intra-pulmonary neuro-epithelial bodies in newborn rabbits. Influence of hypoxia, hyperoxia, hypercapnia, nicotine, re-serpine, L-DOPA and 5-HTP. Cells Tissue Res. 182: 425-440.

Leguen, I, J. P. Cravedi, M. Pisam \& P. Prunet. 2001. Biological functions of trout pavement-like gill cells in primary culture on solid support: $\mathrm{pHi}$ regulation, cell volume regulation and xenobiotic bio-transformation. Comp. Biochem. Physiol., A, Comp. Physiol. 128: 207-222.

Nilsson, S. \& L. Sundin. 1998. Gill blood flow control. Comp. Biochem. Physiol. A Mol. Integr. Physiol. 119: 137-147

Olson, K. R. 1991. Vasculature of the fish gill: anatomical correlates of physiological functions. J. Electron. Microsc. Tech. 19: 389-405.

Scheuermann, D. W. 1987. Morphology and cytochemistry of the endocrine epithelial system in the lung. Int. Rev. Cytol. 106: 35-88.

Zaccone, G., J. M. Lauweryns, S. Fasulo, G. Tagliafierro, L. Ainis \& A. Licata. 1992. Immunocytochemical localization of serotonin and neuropeptides in the neuroendocrine paraneurons of teleost and lungfish gills. Acta Zool. 73: 177-183.

Zaccone, G., S. Fasulo \& L. Ainis. 1994. Distribution patterns of the paraneuronal endocrine cells in the skin, gills and the airways of fishes as determined by immu- 
nohistochemical and histological methods. Histochem. J. 26: 609-629.

Zaccone, G., S. Fasulo \& L. Ainis. 1995. Neuroendocrine epithelial cell system in respiratory organs of air-breathing and teleost fishes. Int. Rev. Cytol. 157: 277-314.

Zaccone, G., A. Mauceri, S. Fasulo, L. Ainis, P. Lo Cascio \& M. B. Ricca. 1996. Localization of immunoreactive endothelin in the neuroendocrine cells of fish gill. Neuropeptides 30: 53-7.

Received em 13.III.2005

Accepted em 09.III.2007 